\title{
Has Differentiated Instruction Gone 'Awry' in Online Teaching and Learning?
}

\author{
Faizah Idrus \\ Kulliyyah of Education, The International Islamic University Malaysia, Kuala Lumpur, Malaysia \\ Nur Afini Zainal Asri \\ Kulliyyah of Education, The International Islamic University Malaysia, Kuala Lumpur, Malaysia \\ Nurin Najihah Baharom \\ Kulliyyah of Education, The International Islamic University Malaysia, Kuala Lumpur, Malaysia
}

\begin{abstract}
Differentiated Instruction (DI) is a classroom strategy that helps teachers to cater their teachings to students with different abilities and learning needs. The issue here is whether DI is still relevant in the online teaching and learning amidst the COVID-19 pandemic. Thus, the aim of this paper is to explore selected ESL teachers' practices of differentiated instructions in their online classes. It also seeks to examine challenges these teachers withstand while implementing DI in their online classrooms. A qualitative design employing the semi-structured interviews and teachers' reflection notes are used as data collection instruments. A total of six English language teachers from three selected schools in Malaysia took part in this investigation. Thematic analysis following Braun and Clarke (2006) is applied. The findings revealed that environmental strain, resources constraint and students' and parents' attitudes are the main challenges in DI while teaching in an online platform.
\end{abstract}

Index Terms-Differentiated Instruction (DI), online teaching and learning, strategies, challenges, ESL teachers

\section{INTRODUCTION}

\section{A. Is Differentiated Instructions still Relevant in Online Teaching and Learning?}

The education scenario has taken a huge turn when the world is plagued with the Covid-19 pandemic. At present, education across the globe demonstrates significant changes in student teaching and learning and the platforms used for lessons' delivery. What is more alarming is the way in which students receive education with the sudden halt of face to face teaching and learning. As Dudley and Osváth (2016) mentioned that characteristics of students vary significantly in relation to their cultural, ethnic, linguistic, academic, socioeconomic and cognitive backgrounds and differing learning needs, online teaching and learning would greatly be a challenge to teachers, students, as well as parents and guardians. While this change can be beneficial for students and/or parents, it can also create pressure for teachers to plan effective instructions that focus on the needs of the diverse groups of students. Despite the fact that scholars (before the pandemic struck) recommended that differentiated instruction (DI) to be a reasonable alternative to address the issue of varying needs, very little information can be obtained to identify whether the same can be carried out in online platforms. The question to what extent do teachers go all out to practice DI, especially when teaching and learning are carried out online, is a rugged terrain to be explored. When DI is concerned, Tomlinson and Imbeau (2010) surmised that it is based on the following sets of assumptions: (a) readiness to learn, interests, learning styles, lived experiences and life circumstances differ in same aged students; ( $b$ there is evident significance in these differences which can impact the students' learning needs; (c) the connection students make between the curriculum and their life experiences along with their interests indicates the quality of learning the students; and (d) the fundamental job of schools is to maximize the potential of each child (www.uwispace.sta.uwi.edu). In addition to online teaching and learning, a new set of assumption can be added to the existing ones which is; students with varying needs, would need specific platforms and/or online tools to cope with the demand of online learning. With the current scenario, more criteria have to be added to the list of assumptions. Thus, the purpose of this study is to investigate selected ESL teachers' practices of differentiated instructions in their online classes. It also seeks to examine challenges these teachers face while implementing DI in their online classrooms.

\section{B. Significance of the Study}

The implementation of mixed-ability classrooms in all secondary schools in Malaysia calls for effective teaching strategies. Hence, DI was introduced as a teaching framework that takes into account students' readiness, interests and background knowledge. Little information was able to be retrieved on DI in the current situation, although a study stated several challenges encountered including lack of time, minimal professional development workshops or 
considering DI as another educational trend that may quickly pass and get replaced with new strategies (Robinson, Maldonado \& Whaley, 2014). A particular study revealed that the gifted and talented students at PERMATApintar (a centre for gifted students) with different skill levels fail to fulfil their learning needs when they were in an inclusion setting in the absence of DI (Hasrul, Hazita \& Azizah, 2015). With students currently learning from home (due to the pandemic) in online teaching and learning, it is interesting to explore how students with differing abilities fair and whether there are other alternative strategies used by teachers to fulfill the needs of their students.

Hence, the objectives that we seek to achieve are to:

1) examine ESL teachers' perceptions regarding the implementation of differentiated instruction (DI) in online teaching and learning classrooms

2) investigate ESL teachers' practices of differentiated instruction (DI) in online classrooms.

3) analyse challenges ESL teachers face when implementing differentiated instruction (DI) online.

\section{Is Differentiated Instruction Still Relevant at the Current Climate?}

Implementing differentiated instruction is essential for teachers who aspire to help develop students of mixed skill levels learn, but the teachers in these classrooms are faced with many challenges even before the Covid-19 pandemic struck (Tamirat \& Xiaoduan, 2020). Based on literatures which pointed to teachers' challenges to practice DI, and students not meeting the standards, there is justification that this study is needed to understand Malaysian ESL teachers' perceptions and what support they need to help overcome any challenges they face. Understanding the kind of support teachers need could lead to educational decision makers offering them professional development which could further promote teachers' effective use of differentiated instruction in online platforms.

\section{LITERATURE REVIEW}

\section{Examining Differentiated Instruction}

Differentiated Instruction (DI) refers to a philosophy of teaching and a proactive student-centered approach for teaching diverse learners in a supported and heterogeneous environment driven by assessment of the instruction (Hellman, 2007; Suprayogi, 2017; Tomlinson, 2014). Similarly, Valiandes (2015) stressed that differentiated instruction is a learning design which calibrate instructions to meet the students' diverse learning needs, provide each student with corresponding level of challenge, and equip support to help students achieve their learning goals. In the same vein, Blaz (2006) opined that differentiated instruction is the standards and curriculum that inform the students of required knowledge and differentiated instruction techniques help teachers guide the students to the knowledge while teaching them how to learn. Hence, the definition of differentiated instruction encompasses the students reaching the same academic goal, but with the tools of differentiated instruction, as for the process of arriving there is unique and different for each student.

Kryza, Duncan, and Stephens (2010) suggested five elements to differentiate in terms of chunk (new information is presented to the learner), chew (the learner has to make sense of the information), check (the teacher checks if the learner has processed the information), environment (tone and setting of the classroom), and content (what we teach). On the other hand, Tomlinson (1999) emphasized that the core of differentiated instruction is flexibility in content, process, and product. Content is what students are to master or learn from the instruction; process is how the students must complete the learning content; and product is how the learning is demonstrated or observed (Bender, 2012; Cox, 2008).

Taylor (2015) surmised differentiating content is when teachers can vary the level of complexity. This means teachers can provide various suitable materials for the same content or syllabus depending on the students' specific needs instead of using textbooks that caters for everyone. Meanwhile for differentiating process teachers can stretch the learning activities based on the students' interests or learning styles. The students can learn the same content by doing various activities that can evoke their interests. Hence, the learning process would not either be too boring or too difficult for them.

According to Chin (2015) many language teachers do not differentiate their instruction in terms of content. This is due to the insufficient resources for language teachers (Kao, 2014; Reese, 2011). However, it is known that the majority of the English teachers differentiate their instruction in terms of process and product, such as flexible grouping (Sun,2015; Yeh, 2012) or tiered assignments (Alavinia \& Sadeghi, 2013; Chen, 2007; Chen et al., 2014; Chien, 2015a, 2015b; Lin, 2014; Tu, 2012). Sun (2015) and Yeh (2012) employed student team achievement for cooperative learning as a differentiated process.

The effectiveness of differentiated instruction is evident. Servilio (2009) conducted a research on the effectiveness of using differentiated instruction to motivate students to read. Students were provided reading materials of their preference, different choice for reflection of reading materials and different methods of connecting their reading via extended researching, composing a song to memorize rules given to George Washington in battle, or picture drawing with their own explanation for the drawings. She found, “An average of $83.4 \%$ of the students' grades improved in reading, $12.5 \%$ remained the same, and $4.1 \%$ of the grades decreased" (Servilio, 2009, p. 10). She went on to suggest that it is imperative that teachers get to know their students and utilize acquired knowledge of their strengths and weaknesses to create activities that are of the students' interest upon using differentiated instruction. This is because the 
research finding shows when students' interests are at the forefront of teachers' planning and preparation, it is possible to fully engage students thus enhance their academic performance over time (Ratcliff et al, 2012). In addition, Tomlinson (1999) found that by investigating differentiated instruction strategies, the students' verbal and writing proficiency are enhanced. Furthermore, Mizell (2010) differentiated instruction is essential in improving students' learning, improve self-esteem, and generate a positive attitude towards the school. Similarly, a study by Morgan (2014) revealed that students have increased motivation and better achievement when differentiated activity was catered to their interests and strengths.

Prior to the implementation of DI, teachers must be able to recognize students' readiness, abilities and needs. Tomlinson (2005) stated that students' readiness refers to students' preparedness for the ability, skill and concept of a given subject. Students' interest also refers to the attention, curiosity and involvement of a student in a given topic (Tomlinson \& Imbeau, 2010). Whereas, according to Tomlinson \& Imbeau (2010) learning profile, which embraces gender, culture, learning styles, multiple intelligences and learning preferences of students, involves a preference for taking in, exploring, or expressing content. These preferences influence the students' proficiency and efficiency in learning.

Several studies have been conducted pertaining to the outcomes of differentiated instruction on students' learning within the Malaysian education system. Esther (2015) investigated the practices of differentiated reading instruction by secondary school teachers in the ESL classroom on two ESL teachers and 76 students' reading skill. This case study involved interviewing two ESL teachers, distributing Multiple Intelligences Survey to 15-year-olds as well as classroom observations. The researcher concluded that, despite the challenges revealed by the teachers when differentiating their lessons, the differentiated lessons had managed to evoke active participation in reading classroom where the activities were structured according to students' level and pace of learning. However, hitherto, no studies have been conducted on DI in online learning platforms. It is interesting to know the strategies teachers use should they implement DI in their online lessons.

Hasrul, Hazita and Azizah (2015) explored the effects of differentiated instruction on the gifted students at the PERMATApintar National Gifted Center from ESL teachers' perspectives. They reported that the teachers agreed that differentiated lessons promote spaces for student-centered with plenty of opportunities for active involvement. Despite receiving several training sessions on differentiated instruction, teachers indicated that designing appropriate strategies for the gifted students was challenging due to time constraints and insufficient guidelines by the authority.

\section{Methodology}

The aim of this research is to understand and uncover ESL teachers' perceptions of differentiated instruction strategies used in their online lessons in the midst of Covid-19. Qualitative research design employing semi-structured interviews was used. Qualitative research is suitable in this investigation as researchers could explore a problem and develop an understanding of the meaning, provide a literature review to justify the problem, state the purpose and research questions, and collect, analyse, and interpret the data.

\section{A. Settings}

The investigation centred around 3 selected schools in Kuala Lumpur, Batu Pahat as well as a school in Selangor.

\section{B. Instruments}

\section{Semi-structured Interview}

The participants consisted of six English language teachers who had had more than 5 years experience as English Language teachers. Purposive sampling was used to select the respondents. Each interview took place approximately 45 minutes. The questions were open ended and revolved around their teaching experience, feelings on using differentiated instruction, online lessons amidst the pandemic, and how their strategies and practices have influenced their students' abilities to progress in their learning.

\section{Respondents}

The target participants of this research were six high school English language teachers. Each of them had had some experiences in carrying out differentiated instructions in their lessons. The gender of the respondents is not taken into consideration.

TABLE 1

PARTICIPANT BACKGROUND INFORMATION

\begin{tabular}{|c|c|c|c|}
\hline & Years Teaching & Years in Current School & Years Using DI \\
\hline FN & 5 & 4 & $4-5$ \\
\hline DB & 21 & 4 & 8 \\
\hline AJ & 5 & 1 & 1 \\
\hline NK & 5 & 1 & 1 \\
\hline KL & 5 & 5 & 3 \\
\hline WM & 5 & 6 & 0.5 \\
\hline
\end{tabular}




\section{ANALYSIS AND DiSCUSSION}

Data analysis of this study involved exploring detailed verbatim transcripts to identify themes found within the teachers' responses to the interview questions. The first three interview questions aimed at collecting information regarding the teachers' professional background particularly their experiences in English language teaching before and after the Covid-19 pandemic, their experience in practicing differentiated instruction as a strategy and the differences of DI face-to-face and having to do it online. All of them had at least five years teaching experience. Most teachers had taught at the same school throughout their teaching career. Majority practiced differentiated instruction since they began teaching in the schools. One exception was WM, who said her first few months of teaching career was "a very challenging journey" as she was new to the area and her experience through practicum was inadequate to implement differentiated instruction and overcome the challenges in the classrooms. Since they had taught a minimum of five years, it appeared that each teacher would have classroom management under control which is necessary to successfully implement differentiated instruction (Tomlinson, 2001).

\section{A. Thematic Coding of Data Source}

TABLE 2

THEMATIC CODING OF DATA SOURCE: SEMI-STRUCTURED INTERVIEWS WITH TEACHERS

\begin{tabular}{|c|c|c|}
\hline $\bar{c}-1$ & Codes Identified & Selected Themes Identified \\
\hline 1. Understanding DI concept & $\begin{array}{l}\text { 1. Use of different strategies } \\
\text { 2. Addressing students' diversity }\end{array}$ & Understanding of DI \\
\hline 2. Perception & $\begin{array}{l}\text { 1. Meeting varying students' needs } \\
\text { 2. Challenging task }\end{array}$ & $\begin{array}{l}\text { 1. DI as an essential approach to teaching } \\
\text { 2. DI as a challenging approach to } \\
\text { teaching }\end{array}$ \\
\hline 3. Utilising DI before the Pandemic & $\begin{array}{l}\text { 1. Differentiated content } \\
\text { 2. Differentiated process }\end{array}$ & $\begin{array}{l}\text { Application of } \\
\text { Differentiated Instruction in ESL } \\
\text { classrooms }\end{array}$ \\
\hline 4. Utilising DI during the Pandemic & $\begin{array}{l}\text { 1. Challenging task to practice DI } \\
\text { 2. Impossible to carry out DI }\end{array}$ & $\begin{array}{l}\text { DI has not been practised thus far during } \\
\text { the pandemic }\end{array}$ \\
\hline $\begin{array}{l}\text { 4. Challenges in school } \\
\text { 5. Challenges in differentiated classrooms }\end{array}$ & $\begin{array}{l}\text { 1. Environmental strain } \\
\text { 2. Resource constraint } \\
\text { 3. Students' attitudes } \\
\text { 4. Connectivity } \\
\text { 5. Attitudes } \\
\end{array}$ & $\begin{array}{l}\text { Challenges to implementing } \\
\text { Differentiated Instruction in ESL } \\
\text { classrooms face to face and online }\end{array}$ \\
\hline 6. Ways to overcome challenges & $\begin{array}{l}\text { 1. Support from Ministry of Education }(\mathrm{MoE}) \\
\text { 2. Support from colleagues } \\
\text { 3. More trainings are needed }\end{array}$ & $\begin{array}{l}\text { Resources and trainings to enhance the } \\
\text { practice of Differentiated } \\
\text { Instruction in online ESL classrooms }\end{array}$ \\
\hline
\end{tabular}

\section{B. Understanding of Differentiated Instruction}

It is imperative for teachers to have a thorough understanding of the DI concept to implement differentiated instruction into professional practice, with its specific strategies, because without such knowledge, differentiation can be impossible to be enforced effectively (Prast et al., 2018). This is because differentiated instruction is not a single arena, but a combination of both conceptual orientation and practical application (Pham, 2012). When asked for their understanding of DI, most of the teachers demonstrated similar responses by acknowledging that differentiation involved providing all students within their diverse classroom community with different avenues for their learning and mastery. DB stated:

So, I cannot just generalize, this group belongs to this group and knows everything. I have to specify their needs. Let's say I give them a test, so I have in that test, I will know this group needs more on writing, so this group needs to learn reading first, give a list of readings for them so that they can write better. Meaning that, for me differentiated learning is... I need to understand what students' needs are in learning language. (DB 21)

FN expressed:

It is a framework of teaching and providing my pupils what they need in the classroom given the fact that we have a wide range of learners in class. In other words, it is how I teach, how I give work, how I assess them based on their diverse ability. (FN 13)

NK asserted:

Based on my own understanding, differentiated instruction is when the teacher adjusts or paraphrases instructions/activities for different groups of students. This can happen either in the same class or through several classes whereby I would use the same rough content of the lesson plan, and then further adjust it to suit the level of the students/classes. (NK 14)

The data showed two specific codes that define differentiated instruction: (1) use of different strategies and (2) addressing students' diversity. (1) Use of different strategies: When asked to define differentiated instruction, DB associated it with the use of a variety of different instructional strategies. She elaborated it with examples: "I will know this group needs more on writing, so this group needs to learn reading first, give a list of readings for them so that they can write better." Use of different strategies is one of the significant aspects used to define differentiated instruction in 
most existing literature. Tomlinson (2014) stated that, differentiated instruction can be implemented through a variety of instructional strategies by differentiating content, process and product that is aligned with students' readiness, interests and learning profiles. Similarly, Turner, Solis and Kincade (2017) highlighted that to use appropriate instructional strategies, teachers need to take into account their students' individual differences. Based on the above literature, it can be postulated that the definition given by the teacher is appropriate in terms of the importance of utilizing multiple instructional strategies to cater to students' needs.

It was observed that while emphasizing variation in instructional strategies, FN, AJ, KL and NK articulated different instructional strategies aligned with students' diversity. The teachers stressed students' diversity through expressions such as "a wide range of learners in class", "students with different abilities" and "different groups of students". In addition, students' diversity was supported with elaborations by the teachers. For instance, FN reported, "it is how I teach, how I give work, how I assess them based on their diverse ability". NK also noted, "I would use the same rough content of the lesson plan, and then further adjust it to suit the level of the students/classes". The findings illustrated similar strands describing differentiated instruction as attending to students' individual needs by providing tasks and activities that are appropriate to the level of the students.

The above findings are in line with literature explicating that addressing students' diversity is one prevalent aspect of differentiated instruction. Tomlinson (2001) emphasized teachers who utilised DI must take into consideration students' levels, needs and interests. It is how an instruction is tailored to meet the needs of diverse learners so that all students within a classroom can learn effectively, regardless of differences in their ability. And when the differences are well accommodated, students learn best (Tomlinson, 2005). These literatures validated the current findings of addressing students' diversity which could be an appropriate way to define differentiated instruction.

Strikingly, the result revealed that, although the model of differentiated instruction describes differentiation using three main components: (1) content, (2) process and (3) product, all teachers focused their definition heavily on the content and process only. None of them highlighted product to define the concept. Moreover, the teachers did not use common vocabulary associated with the approach such as content, process or product. This shows that the teachers possess limited knowledge about differentiated instruction in general, hence, it could be hypothesised that differentiated instruction is not only a challenge to practice, but is also difficult to understand.

\section{Differentiated Instruction as an Essential Approach to Teaching (Face-to-face)}

In general, there was a mutual feeling among the teachers that differentiated instruction was an essential approach to teaching face-to-face that assisted them in meeting varying students' needs. KL stated: I feel that it is very effective in catering to the needs of the pupils and it can mediate my teaching based on what they need. (FN 22). Sharing on its importance, DB responded while providing some examples:

I find it much easier in order to understand some students. When I try to reach them, I can understand their problem better. For example, disciplinary problem, they don't do their work, but if I go to them and then I try to give simple exercises to see whether they can actually understand the language or not. (DB 49)

Similarly, NK declared:

Giving instructions from the front and asking for a choral response to your- "Do you understand?" prompt just never really works, does it? Whether or not the students answer with a "Yes", it is undeniably harder to scan whether they truly understand their task/lesson for the day or not if you try to assess a large group of 25-35 students at a time. (NK 26)

Based on the information recorded above, it indicated that they felt strongly that the DI carried out face-to-face was a valuable and necessary approach to teaching. The teachers realized that implementing DI enabled them to meet the needs of all students. This theme is aligned with Tomlinson's (2005) view that teachers are increasingly aware that they need to teach differently to cater to the growing population of diverse students.

\section{Differentiated Instruction as a Challenging Approach to Teaching amidst the Pandemic}

DI had a different turn when the teachers were compelled to teach online. Although the majority of the teachers had a positive perception of differentiated instruction, AJ, FN and especially WM (who was relatively new to DI) had notably negative perception of the approach with regard to the amount of support from parents and colleagues, trainings as well as students' attitudes towards online learning. The finding revealed that they viewed the implementation of DI as challenging, time consuming and they notoriously were ill-prepared, mentally and emotionally. WM had this to say:

So, I know this is going to be a very challenging journey for me because I am new to this and my experience does not include DI. Considering the pandemic situation we are going through right now, it is extremely difficult to teach the students as they do not join the online class let alone for me to apply the differentiate instruction. Hence, I do not carry out DI...just normal lessons. (WM 28)

While FN added: "But I personally think that it is quite time consuming to prepare such lesson especially when you know half the class won't be there online...". (FN 23). Although DB and KL could be considered as 'masters' of DI as they had many years of practicing DI in their classrooms, they too were quite skeptical on the effectiveness of carrying out this strategy online. KL mentioned that she was very positive at the beginning of the pandemic and had hoped that classes will run as usual. Her expectation was totally crushed when many of her usually responsive students reacted otherwise. She continued by saying that the reasons behind this might include internet connectivity, shared devises with 
other siblings, no proper study area at home, parents' squabbles and many other possible factors.

This finding corresponds with Lunsford (2017) in which teachers agreed that implementing differentiated instruction could be beneficial to students' learning, however they also agreed that there are challenges to it. As revealed in Merawi's (2018) study, teachers' negative perceptions towards differentiated instruction is due to a number of prevailing factors such as: time constraints, knowledge gaps, large class size, lack of resources, poor leadership support, lack of commitment from teachers and lack of learning interest on students side. However, we have found that no study had yet to describe the challenges of carrying out DI online, perhaps due to the recentness of the issue.

\section{E. Challenges to Implementing Differentiated Instruction}

Based on the findings garnered from the interviews, there are several main challenges for the participants to implement DI online, which are among others; students attendance, lack of training, environmental strain, resource constraint and students' attitudes. The first main challenge is students' attendance in online DI. Many teachers are baffled of what to do with students not appearing online. AJ shared her experience when only two students appeared in her class despite many reminders. The most she could do was to personally send a message to parents telling them that their children were absent in her class. Next is the lack of training on DI. Not many trainings were provided to the teachers on DI. To add to that, online trainings in general is scarce. KL said that thus far she had only attended one DI workshop and that was it. The environmental strain is another factor. From the interviews, we identified three factors that contributed to environmental strain. The most prominent and biggest challenge shared by all respondents is time. There are two aspects of time that played some parts in the challenge. Firstly, it is time consuming to implement DI. FN expressed her thoughts: 'Seriously, teachers need to be ready and prepare all materials and plans before the class. Sometimes, a week or two ahead. (FN58). Meanwhile, NK added: 'As much as the more focused methods work, we simply have no time to prepare the activities/lessons every time'. (NK 88)

Correspondingly, Joseph et al. (2013) reported that teachers need to spend long hours for planning, organising and scheduling individual and groups in a large class setting when the strategy was implemented. Furthermore, in a study conducted by Mariam Shareefa et al. (2019), in which they found out that time is the highest ranking challenge out of six challenges. Another aspect of time that contributed to a part of the challenge is time constraint. The participants stated that they basically did not have enough time to implement DI due to insufficient class hours with the students. DB stated: 'I can use that for two periods of learning in the class and also if I have just one period, I cannot do that... (DB 144)

This is also acknowledged by AJ, who shared: 'English usually has a 1-hour period per session, which could be quite tight to implement the differentiated instruction. (AJ 76). Concurrently, NK added:

Another aspect of time is in the classroom itself... things that are out of our control such as the technological part or even the things like students coming up late from the lab/library, or the previous teacher is taking your time... All those little things can affect your plans and activities. (NK 91)

Thus, it can be seen that time is the biggest challenge in implementing differentiated instruction. NK even labeled time as her nemesis (NK88).

The next factor that contributes to environmental strain is tiredness. Tiredness could be from preparing materials for DI while handling other school matters. FN firmly stated about depletion of energy: 'I think it could be quite exhausting as we are juggling with many other work too'(FN 59). In order to implement DI, teachers need to identify students' abilities. Based on their abilities, teachers can provide various assignments based on skill levels or interests to meet the needs of all students (Dixon et al., 2014). Hence, it is understandable if teachers perceive DI as tiring because a lot of effort is needed to plan differentiated lessons. However, with almost every class conducted online, they are not just tired but mentally drained to get students to do different things at the same time, if ever the students decided to appear that day. The last factor that led to environmental strain is the large number of students in a class. The large number of students in a class is a normal situation in almost every school during the face-to-face lessons. DB emphasized:

The number of students that should be in the class is around 20 to 25 . Not more than that. Because I've been teaching this one class, they have around 22 students, okay, and it is easier for me to teach them effectively because less number of students. (DB 161)

According to Ford \& North Central Regional Educational Lab, N.O (2005) small group instruction can play a pivotal role in a differentiated classroom. In addition, small group instruction allows the teachers to work more closely with a smaller number of students to help them achieve more (Lipson \& Wixson, 2012). Moreover, based on a study by Aldossari (2018), the biggest challenges facing male and female teachers in the use of DI strategies related to the school environment is "the density of students per classroom" with the arithmetic mean of 4.52 . Hence, the number of students in a class can affect the implementation of differentiated instruction. Nevertheless, the inconsistencies of students' attendance in the online class made it problematic for teachers to carry out DI systematically no matter how small the group maybe.

The next main challenge identified from the interviews is resources. It is said that teachers do not have enough resources to use for the teaching and learning sessions. DB stressed: 'We don't have enough materials for example books, okay, reference books that caters to the students' needs'. (DB 151)

Tomlinson (2005) stated that differentiated instruction means responsive teaching whereby the teachers embrace the differences and tailor instruction to the needs of the students and when the differences are well accommodated, students 
learn best. Hence, the implementation of DI needs various activities that can cater to the students' needs and complement their abilities. This point was also stressed by Idrus (2014) in that in examining the activities used in the classroom, teachers would be able to be responsive to varieties of students' needs. Teachers need suitable resources that can aid them to come out with appropriate and sufficient activities for the students.

The final challenge gathered from the interviews is students' attitude. Students' attitude towards learning is crucial to determine the effectiveness of teaching and learning sessions. AJ expressed: 'If the student is lazy and does not want to cooperate with the teachers...that would be difficult' (AJ 74). The implementation of DI could be challenging if the students do not show any interest to learn in the first place. According to a study by Aldossari (2018) it showed that "students' weak motivation for learning" is the third lowest challenge out of eight challenges of implementing DI. This shows students' attitude definitely has an impact towards differentiated instruction. On the other hand, the greatest challenge is the "weakness of students' conviction in using the DI strategy", which means students do not have confidence in the differentiated class (Aldossari, 2018). This could be due to various reasons. For teachers to differentiate effectively, they must first recognize the different aspects of the learning needs of the students in the classroom (Herrelko, 2013; Latz \& Adams, 2011). Therefore, it is crucial for teachers to get to know their students first before implementing differentiated instruction. AJ also stressed: 'After getting know your students' needs and abilities then you can slowly start implement the differentiated instruction. Do it step by step, do not do it in a rush'. (AJ 103)

Based on the outcomes above, it showed that the teachers were aware of these challenges upon implementing DI even before the pandemic struck. Hence, these challenges should be addressed properly by finding the right solutions to assure the success of the implementation of differentiated instruction in classrooms be it face-t-face or online.

\section{CONCLUSION}

In sum, we explored ESL teachers' perceptions towards implementing differentiated instruction (DI) in online teaching and learning. Teachers' perception has been identified as one of the significant factors influencing teachers' behavior. As such, studies examining teacher-thinking have proven that there is a significant relationship between teachers' thinking, beliefs and attitudes associated with the behavior and actions (Rosidah \& Nurahimah, 2020). In this regard, research on teachers' perception of DI and associated relationships with the adoption of the approach in teaching is abundant (Nicolae, 2013; Chin-Wen, 2015; Merawi, 2018; Tamirat \& Xiaoduan, 2020). However, DI in online teaching and learning is scarce and relatively new. It has long been argued that teachers' perception of DI is inconsistently changing in that many believe that all students are capable of learning within a mixed ability classroom despite varying platforms (face-to-face and online). Mariyam et al. (2019) opined that the positive perceptions held by teachers regarding differentiated instruction is expected to enhance the adoption of such teaching practices in curriculum delivery. Similarly, Charles and Luard (2018) qualitative study revealed that the use of differentiated instruction is prevalent when teachers perceive that differentiated instruction is essential in a mixed skill level classroom. This implies that having a positive perception of differentiated instruction is influential in increasing the use of the approach in the classrooms. Sadly, this is not the case in the current study. Online DI can be seen as very challenging or even a failure to some ESL teachers.

Discourse constructed from the interviews was used to explore the feelings and emotions to unearth what is actually happening on the ground. It was revealed that the teachers are still grappling with the notion of DI, and it was made worse when classes had to be conducted online due to COVID 19 pandemic. For teachers to successfully implement DI, they must have a clear notion of DI as well as the probability to apply DI on different platforms. Some felt strongly that differentiated instruction was a valuable and necessary approach to teaching but to implement it online needs time as well as ample trainings. However, it is not uncommon that some of them realized that utilising DI enabled them to meet the needs of all students, which is a relief albeit with many trials and tribulations. It can be concluded that DI has really taken its toll in online teaching and learning but not to the point of 'gone awry'. Finally, the study was restrained by certain limitations. Firstly, sampling was restricted to a specific region of the country reducing its generalisation to other regions. All of the participants were Malay ESL teachers. This study focused mainly on differentiated instruction through selected teachers' point of views. Hence, future studies could be adapted to find out perspectives from students, school administrators, and officers from Ministry of Education. Future studies could also include observations. This is to see how the teachers would implement differentiated instruction in online classrooms.

\section{ACKNOWLEDGMENTS}

We would like to thank Research Management Centre, IIUM for the grant awarded for the Research Initiative Grant Scheme (RIGS16-372-0536).

\section{REFERENCES}

[1] Adams, P., \& Townsend, D. (2014). From action research to collaborative inquiry: a framework for researchers and practitioners. Education Canada, 54(5), 12-15.

[2] Alba, F. (2015, September 3). Collaborative Action Research (CAR). Retrieved November 12, 2020, from https://education.gov.scot/improvement/Documents/sacfi12b-CAR overview.pdf. 
[3] Al-Subaiei, M. S. (2017). Challenges in mixed ability classes and strategies utilized by eli teachers to cope with. Journal of English Language Teaching 10(6), 182-189.

[4] Bailey, C. \& Bridges, D. (1983). Mixed Ability Grouping - A Philosophical Perspective. New York: Routledge.

[5] Bernard, H.R. (2002). Research Methods in Anthropology: Qualitative and quantitative methods. 3rd edition. AltaMira Press, Walnut Creek, California, Applied Social Research Methods Series.

[6] Boyatzis, R.E. (1998). Transforming Qualitative Information: Thematic Analysis and Code Development. Thousand Oaks, CA: Sage Publications.

[7] Braun, V., \& Clarke, V. (2006). Using thematic analysis in psychology. Qualitative Research in Psychology, 3, $77-101$.

[8] Braun, V., Clarke, V., \& Terry, G. (2015). Thematic Analysis. In P. Rohleder \& A. C. Lyons (Eds.), Qualitative Research in Clinical and Health Psychology (pp. 95-113). Houndmills, Basingstoke, Hamphshire, UK: Palgrave Macmillan.

[9] Brown, G. H. (1947). A comparison of sampling methods. Journal of marketing, 6, 331-337.

[10] Bryman, A. \& Bell, E. (2007). Business Research Methods. 2nd edition. Oxford; New York: Oxford University Press, cop. 2007.

[11] Burgess, R.G. (1984). In the Field: An Introduction to Field Research. London: Unwin Hyman.

[12] Castro, E. (2015). Helping English language learners succeed in school. The Education Digest, 80 (7), 44-47

[13] Corey, S.M. (1953). Action Research to Improve School Practices. New York: Teachers College Bureau of Publications, Columbia University.

[14] Creswell, J. (2009). Research design: Qualitative, quantitative, and mixed methods approaches (3rd ed.). Los Angeles: Sage.

[15] De Jesus, O. N. (2012). Differentiated instruction: can differentiated instruction provide success for all learners? National Teacher Education Journal, 5(3), 5-11. Retrieved from Education Research Complete database. (Accession No. 84313770).

[16] Dudley, E. and E. Osváth. (2016). Mixed-Ability Teaching. Oxford: Oxford University Press.

[17] E. J. Prast, E. Van de Weijer-Bergsma, E. H. Kroesbergen, and J. E. H. Van Luit. (2018). Differentiated instruction in primary mathematics: Effects of teacher professional development on student achievement," Learn. Instr., vol. 54, pp. 22-34.

[18] Ginja, T. G., \& Chen, X. (2020). Teacher Educators' Perspectives and Experiences towards Differentiated Instruction. International Journal of Instruction, 13(4), 781-798. https://doi.org/10.29333/iji.2020.13448a.

[19] Hammersley, M. and Traianou, A. (2012). Ethics in Qualitative Research: Controversies and Contexts. London: Sage Publications Ltd.

[20] Henderson, L. (2017). "Someone Had to Have Faith in Them as Professionals": An Evaluation of an Action Research Project to Develop Educational Leadership Across the Early Years. Educational Action Research, 25(3), 387-401.

[21] Hines, M. B., \& Conner-Zachocki, J. (2015). Using Practitioner Inquiry Within and Against Large- Scale Educational Reform. Teacher Development, 19(3), 344-364.

[22] H. L. Pham. (2012). "Differentiated instruction and the need to integrate teaching and practice," J. Coll. Teach. Learn, 9(1), $13-20$.

[23] Idrus, F. (2014). Initiating Culturally Responsive Teaching for Identity Construction in the Malaysian Classrooms. English Language Teaching, 7(4), 53-63.

[24] Ishak, N.M., \& Bakar, A.Y.A. (2017). Identification Process of Young Gifted Learners: The Malaysian Experience. Journal for the Education of Gifted Young Scientists, 5, 2, 71-81.

[25] Jelas, Z. M. \& Mohd Ali, M. (2012). 'Inclusive Education in Malaysia: Policy and Practice', International Journal of Inclusive Education. DOI: 10.1080/ 13603116.2012.693398.

[26] Jin, E. A. W. N. (2015). Teachers' practices of using differentiated reading instruction in ESL classroom. Wawasan Open University.

[27] Kepol, N. (2017). Quality Malaysian English language teachers: Examining a policy strategy. Malaysian Journal of Learning and Instruction, 14(1), 187-209.

[28] Kincade. (2017). "Differentiating instruction for large classes in higher education.," Int. J. Teach. Learn. High. Educ., vol. 29, no. 3, pp. 490-500.

[29] Lodico, M., Spaulding, D. T., \& Voegtle, K. H. (2010). Methods in educational research: From theory to practice (Laureate Education, Inc., customed.). San Francisco, CA: John Wiley \& Sons.

[30] Lunsford, K.J. (2017). Challenges to Implementing Differentiated Instruction in Middle School Classrooms with Mixed Skill Levels. PhD Thesis, Walden University. https://scholarworks.waldenu.edu/dissertations.

[31] Malaysia Education Blueprint, M. (2013). Malaysia Education Blueprint 2013 - 2025. Education 27(1): 1-268. doi: 10.1016/j.tate.2010.08.007.

[32] Mariyam Shareefa, Visal Moosa, Rohani Mat Zin, Nor Zaiham Midawati Abdullah and Rosmawijah Jawawi. (2019). Teachers' Perceptions on Differentiated Instruction: Do Experience, Qualification and Challenges Matter? International Journal of Learning, Teaching and Educational Research. Vol. 18(8).214-226. https://doi.org/10.26803/ijlter.18.8.13.

[33] Marks, D. and Yardley, L. (2004). Research methods for clinical and health psychology. London: SAGE Publication

[34] Manesi, S., \& Betsi, S. (2013, March 4). (PDF) Collaborative Action Research Projects. Retrieved November 12, 2020, from https://www.researchgate.net/publication/256546932_Collaborative_Action_Research_Projects_the_role_of_Communities_of_ Practice_and_Mentoring_in_enhancing_teachers'_Continuing_Professional_Development.

[35] Maxwell, J. A. (1996). Qualitative Research Design: An Interactive Approach London Merriam, S. (2009). Qualitative Research: A Guide to Design and Implementation. San Francisco, CA: Jossey-Bass.

[36] Melesse, T. (2018). Differentiated instruction: Perceptions, practices and challenges of primary school teachers. Science, Technology and Arts Research Journal, 4(3), 253. doi: 10.4314/star. v4i3.37.

[37] Miles, M. B., \& Huberman, A. M. (1994). Qualitative Data Analysis: An Expanded Sourcebook. Thousand Oaks, CA: Sage Publications.

[38] Mohd Hasrul, K., Hazita, A., \& Zahidi, A. M. (2015). Differentiation Practices among the English Teachers at PERMATApintar National Gifted and Talented Center. Asian Social Science, 11(9), 346-351.

[39] Mohd Hasrul, K., Hazita, A., \& Zahidi, A. M. (2017). Differentiated instruction strategies in English language teaching for 
gifted students. Journal of Applied Environmental Biological Science, 7(1S),78-90, 2017

[40] Palmer, Cathryne \& Bolderston, Amanda. (2006). A Brief Introduction to Qualitative Research. Canadian Journal of Medical Radiation Technology. 37. 16-19. 10.1016/S0820-5930(09)60112-2.

[41] Robinson, L., Maldonado, N., \& Whaley, J. (2014). Perceptions About Implementation of Differentiated Instruction. Paper presented at The Annual Mid-South Educational Research (MSERA) Conference. Retrieved from Education Resources Information Center (ERIC) No. ED554312.

[42] Rosidah Ramli, Nurahimah Mohd. Yusoff. (2020). Self-efficacy and Differentiated Instruction: A Study among Malaysian School Teachers. Universal Journal of Educational Research, 8(4), 1252 - 1260. DOI: 10.13189/ujer.2020.080416.

[43] RAJA, V. S. (2020). Difference between Probability and non-probability sampling. Market Research. Retrieved 1November 2020, from https://pgdabm1618.wordpress.com/2017/01/15/difference

[44] Said, M., \& Ehsan, N. (2019). The Effects of Differentiated Instruction on Students' Language Attitude and Critical Thinking in an ESL Context (Doctoral dissertation, University of Sheffield).

[45] Shenton, A.K. (2004). Strategies for ensuring trustworthiness in qualitative research projects. Educ. Inf., 22, 63-75.

[46] Steffen, Edith. (2016). Ethical considerations in qualitative research.

[47] Sternberg, R. and L. Zhang. (2005). Styles of Thinking as a Basis of Differentiated Instruction. Theory into Practice, 44(3): 245-253.

[48] Taherdoost, Hamed. (2016). Sampling Methods in Research Methodology; How to Choose a Sampling Technique for Research. International Journal of Academic Research in Management. 5. 18-27. 10.2139/ssrn.3205035.

[49] Taylor, B. K. (2015). Content, process, and product: Modeling differentiated instruction. Kappa Delta Pi Record, 51(1), $13-17$. doi:10.1080/00228958.2015.988559.

[50] Thomson, V. (2009). Impact of differentiation on instructional practices in the elementary classroom (Doctoral Dissertation, Walden University). Retrieved July 2, 2010 from Proquest Research Database.

[51] Tomlinson, C. A. (1999). Leadership for differentiated classrooms. The School Administrator, 56(9), 6-11.

[52] Tomlinson, C.A. (2001). How to Differentiate Instruction in Mixed Ability Classrooms (2nd ed.). Alexandria: Association for Supervision and Curriculum Development.

[53] Tomlinson, C. A. (2005). Traveling the road to differentiation in staff development. J. Staff Dev., vol. 26, no. 4, p. 8-12.

[54] Tomlinson, C. A., \& Imbeau, M. B. (2010). Leading and Managing a Differentiated Classroom. Virginia: ASCD Publications.

[55] Tomlinson, C. A., \& Imbeau, M. B. (2012). Common sticking points about differentiation. School Administrator, 69(5), 18-22.

[56] Tomlinson, C. A. (2014). The differentiated classroom: Responding to the needs of all learners. Ascd.

[57] Trachoma, William M.K. (2006). Sampling. Retrieved October 28, 2020 from http:// www.socialresearchmethods.net/kb/sampling.php

[58] W. D. Turner, O. J. Solis, and D. H. Winifred, A. (2014). NUTP wants less paperwork, more time with students. http://www.themalaymailonline.com/malaysia/article/nutp-wants-less-paperworkmore time-with-students. Accessed on 10 May 2020.

[59] Yasmin, Farhana. (2018). Challenges to Computer Assisted Language Teaching at University Level. International Journal of Language \& Literature. 6.10.15640/ijll. v6n2a10.

[60] Yin, R. K. (2003). Case study research, design and methods, Newbury Park, CA, SAGE.

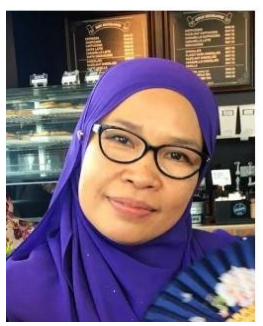

Faizah Idrus is an Associate Professor at Kulliyyah of Education, International Islamic University Malaysia. Her research interests include but not confined to ELT, Language, Identity and Community, Teacher Education, Cultural Intelligence, CRT and a few others

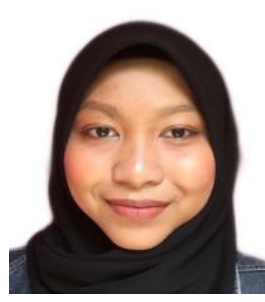

Nur Afini Zainal Asri was born on $22^{\text {nd }}$ November 1998 in Sultanah Nora Ismail Hospital, Batu Pahat, Johor. Afini is currently undergoing her degree in Teaching English as a Second Language at International Islamic University Malaysia in Gombak. She completed her foundation in TESL in 2017 at Universiti Teknologi MARA in Dengkil. 


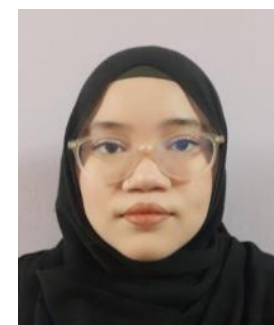

Nurin Najihah Baharom was born on $6^{\text {th }}$ July 1997 and raised in Kuantan, Pahang. She completed her foundation at UIA Foundation Center in Petaling Jaya and pursuing her degree in Teaching English as a Second Language at International Islamic University, which is situated in Gombak, Kuala Lumpur. She is currently in the final semester of her degree. 